Supplement of Biogeosciences, 15, 5929-5949, 2018

https://doi.org/10.5194/bg-15-5929-2018-supplement

(C) Author(s) 2018. This work is distributed under

the Creative Commons Attribution 4.0 License.

(c) (1)

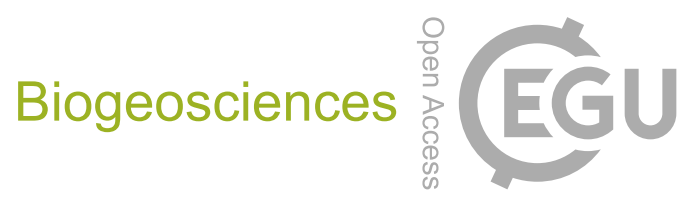

Supplement of

\title{
Reviews and syntheses: Carbon use efficiency from organisms to ecosys- tems - definitions, theories, and empirical evidence
}

Stefano Manzoni et al.

Correspondence to: Stefano Manzoni (stefano.manzoni@natgeo.su.se)

The copyright of individual parts of the supplement might differ from the CC BY 4.0 License. 


\section{Estimating carbon-use and carbon-storage efficiencies}

\subsection{Leaves}

Leaves are responsible for fixing atmospheric $\mathrm{CO}_{2}$, thereby representing the entry points of $\mathrm{C}$ into terrestrial ecosystems. By measuring net photosynthesis and respiration, CUE at the leaf level can be defined as the ratio of net to gross photosynthetic rates,

$$
\mathrm{CUE}_{\text {leaf }}=\frac{\text { Net photosynthesis }}{\text { Gross photosynthesis }}=\frac{A_{\text {net }}}{A_{\text {net }}+R_{\text {dark }}+R_{\text {photo }}},
$$

where the net photosynthetic rate $\left(A_{n e t}\right.$, also referred to as net $\mathrm{CO}_{2}$ assimilation) is the difference between gross photosynthesis and the sum of photorespiration $\left(R_{\text {photo }}\right)$ and mitochondrial respiration $\left(R_{\text {dark }}\right)$. Photorespiration occurs when the photosynthetic enzyme Rubisco (which fixes $\mathrm{CO}_{2}$ ) experiences non-saturating $\mathrm{CO}_{2}$ conditions in the presence of $\mathrm{O}_{2}$, as is the case for most plants in our current atmosphere. We therefore include photorespiration costs in the term gross photosynthesis in Eq. (S1), as done in other studies (Way and Sage, 2008), although cannot account for that in our calculations due to data limitations. In leaves, mitochondrial respiration proceeds in both the dark and in the light, although respiration rates are often lower in the light than in the dark. As the phenomenon of light-suppression of respiration is poorly understood and leaf respiration in the light is difficult to measure (Tcherkez et al., 2017), we use dark respiration rates and assume that they represent respiration rates over a 24hour period. Moreover, photorespiration is neglected in our calculations, because the compensation point was not reported in the dataset we used (Atkin et al., 2015), so that our estimates of leaf CUE are slightly overestimated.

\subsection{Individual organisms (autotrophs and heterotrophs)}

The balance of growth plus exudation and respiration defines the CUE of individual organisms (Eq. (5) in the main text),

$$
\mathrm{CUE}_{\text {organism }}=\frac{\text { Net biomass production }+ \text { exudation }}{\text { C uptake }}=\frac{G+E X}{U}=1-\frac{E G+R}{U},
$$

where $R$ includes all respiration components shown in Eq. (7) in the main text. The equalities in Eq. (S2) show how CUE can be estimated from different combinations of observations: net biomass accretion $(G)$ and exudation rate $(E X), \mathrm{C}$ consumption from the resource pool ( $U$ - organic $\mathrm{C}$ for heterotrophs or $\mathrm{CO}_{2}$ for autotrophs), and respiration rate $(R)$ (Geyer et al., 2016; Slansky and Feeny, 1977; Cannell and Thornley, 2000). While EX should be included in these calculations, it is generally neglected or implicitly considered as autotrophic respiration when calculating plant CUE. Neglecting exudation in terrestrial plants can lower the estimated NPP by up to $30 \%$ (Clark et al., 2001), whereas the rate of exudate production by most heterotrophs is poorly constrained. Therefore, it is possible that neglecting exudation lowers estimated CUE of heterotrophs as it does for plants, but the extent of this error can be evaluated only after exudate production rates (extracellular polysaccharides and enzymes) are estimated.

For all organisms, when net biomass production and respiration are measured, cell turnover and other organic $\mathrm{C}$ losses during the incubation time are not accounted for, so that the estimated values should often be interpreted as 'apparent' CUE. This can be challenging when incubation times are long. For plants, gross rates of $\mathrm{C}$ uptake are estimated by summing up net photosynthesis measured during the day to the respiration rate obtained 
assuming that night and day respiration are comparable; if heterotrophic respiration is included in the measurements, it needs to be subtracted to isolate the autotrophic component (Wang et al., 2015) (see also Sect. 1.3). CUE of non-vascular vegetation, such as mosses and lichens, is defined in the same way as CUE of vascular plants with empirical estimates typically using respiration and gross photosynthesis to estimate CUE. Consequently, these studies share the same limitations noted for plants. Only few studies traced how much of newly acquired $\mathrm{C}$ is incorporated into biomass using isotopes (Street et al., 2013; Woodin et al., 2009; Lotscher et al., 2004).

\subsection{Primary producer communities}

CUE of plant communities can be defined as for individual plants, but using data at a larger scale $(\sim 100-1000 \mathrm{~m})$ and covering the whole range of species and age classes in a certain community. In this case, the control volume conceptually comprises all plant organs including roots. It is thus virtually impossible to accurately measure all $\mathrm{C}$ exchange rates across the boundaries of this control volume, so that major assumptions on the contribution of autotrophs to measured net $\mathrm{C}$ fluxes have to be made (Clark et al., 2001). At this scale, production is defined by the net primary productivity (NPP) and C uptake by the gross primary productivity (GPP), so that (DeLucia et al., 2007; Zhang et al., 2009),

$$
\mathrm{CUE}_{\text {plant community }}=\frac{\text { Net primary productivity }}{\text { Gross primary productivity }}=\frac{\mathrm{NPP}}{\mathrm{GPP}}=1-\frac{R_{a}}{\mathrm{GPP}} \text {. }
$$

At the stand scale, GPP is obtained by flux partitioning from eddy covariance measurements of net ecosystem exchange (NEE) (Lasslop et al., 2010; Reichstein et al., 2005). NPP can be derived from the increase in biomass of the different biomass compartments (stem, branches, foliage, roots), but should also include the $\mathrm{C}$ allocated to understory, herbivory, reproductive organs, root exudates, volatile organic compounds and $\mathrm{CH}_{4}$ emissions (Luyssaert et al., 2007; Clark et al., 2001). However, below-ground NPP as well as these latter C fluxes are extremely difficult to capture and thus often either ignored or very uncertain (Clark et al., 2001), creating some ambiguities in how CUE plant community is defined. As shown in Eq. (5) in the main text, plant community CUE should be calculated by including both net biomass increments and exudation rates. When only net biomass increments are available, the terms gross growth efficiency (GGE) or equivalently biomass production efficiency (BPE) are more accurate (as in Campioli et al., 2015; Vicca et al., 2012). GGE estimates are reported in an extensive global database for forest sites, including direct measurements, indirect estimates (derived from measurements of other $\mathrm{C}$ fluxes) and model results (Luyssaert et al., 2007). This dataset has been recently expanded to grasslands and croplands (Campioli et al., 2015) (data used in Fig. 5-7).

At the global scale, observation-based GPP products rely on either spatial extrapolation of diagnostic models relating site-level eddy covariance-derived GPP to climate, vegetation type and remote sensing indices (Beer et al., 2010), or on relations to the fraction of absorbed photosynthetic active radiation measured by satellite remote sensing (e.g., MODIS, with resolution $\sim 1000 \mathrm{~m}$ ) (Zhao et al., 2005). Global observation-based NPP products in turn are solely available from combining satellite-based GPP estimates with model assumptions on biomass allometry and autotrophic respiration (Tum et al., 2016; Zhao and Running, 2010).

In addition to the existing dataset for vascular plant communities, we also estimated CUE for nonvascular vegetation using reported respiration and photosynthetic rates. In productive forest and grassland ecosystems, non-vascular vegetation usually contributes only a small part to total carbon uptake. Exceptions are 
high values of up to $60 \%$ at high latitudes (Turetsky et al., 2010). Because of this small contribution, it is impractical to estimate CUE of non-vascular vegetation by methods such as eddy covariance. In less productive drylands where non-vascular vegetation may be the main primary producers, samples of complete crusts can be collected in the field and the CUE of these communities can be derived from measured net photosynthesis and dark respiration in the laboratory (see references in Table S2).

\subsection{Microbial communities}

While conceptually similar to the definition for individual organisms, interpreting CUE at the whole microbial community level (in either terrestrial or aquatic systems) is complicated by the presence of inactive organisms and by the co-occurrence of a range of life history strategies with their potentially different CUE (Geyer et al., 2016; del Giorgio and Cole, 1998). CUE is estimated typically by measuring (at least) two among the C fluxes relevant for microbial $\mathrm{C}$ budgets: substrate consumption (assumed to be equal to $\mathrm{C}$ uptake; i.e., neglecting losses of depolymerized $\mathrm{C}$ before uptake by microorganisms), net microbial growth, and respiration rates (Manzoni et al., 2012). These $\mathrm{C}$ exchanges are generally measured under controlled conditions in relatively small incubation systems ( $<1 \mathrm{~L}$ volume) and in transient conditions. A substrate (often isotopically-labelled) is generally added to trace $\mathrm{C}$ uptake into biomass and thus determine the changes in $\mathrm{C}$ pools required to estimate CUE. In marine sediments, ${ }^{3} \mathrm{H},{ }^{14} \mathrm{C}$, or ${ }^{13} \mathrm{C}$-uptake experiments are conducted to estimate microbial growth rates, but application of this technique in sediments is challenging, and the contribution of biomass turnover is poorly constrained (an issue shared with measurements in soil).

The concentration and choice of substrate (more or less similar to compounds used in natural conditions)

and the length of the incubation period affect the obtained CUE (see Sect. 4.1 in the main text). Labile substrates and more generally higher C concentrations result in higher CUE values (Frey et al., 2013; Öquist et al., 2017; del Giorgio and Cole, 1998; Bolscher et al., 2017), while increasing incubation time from a day to a week or more results in lower apparent CUE, as necromass is recirculated and used (Ladd et al., 1992; Öquist et al., 2017). Previous reviews discuss these methodological issues in depth (Geyer et al., 2016; Sinsabaugh et al., 2013; del Giorgio and Cole, 1998).

Microbial exudation rates cannot be readily measured in soils and available evidence of the fate of $\mathrm{C}$ in extracellular products is limited. Even though the standing extracellular polysaccharide mass can be comparable to that of the microbial biomass (Marchus et al., 2018), without knowing the turnover rate of these extracellular compounds, production rates cannot be estimated. In contrast, the turnover rate of extracellular enzymes has been estimated (Allison, 2006), but not their standing mass, which again hampers our understanding of production rates. In one article, ${ }^{14} \mathrm{C}$ has been used to identify extracellular metabolites, showing that in laboratory conditions their accumulation is negligible in aerobic soil samples, but not in permanently anaerobic ones (Šantrůčková et al., 2004). Therefore, it is difficult to quantify potential errors in CUE estimates based on biomass increments, but neglecting exudation rates (i.e., when CUE is approximated by GGE), compared to estimates based on substrate uptake and respiration rates (Eq. (5) in the main text).

\subsection{Food webs}

The efficiency of $\mathrm{C}$ (and energy) transfer in terrestrial and aquatic food webs has been defined as the ratio of $\mathrm{C}$ used at a certain trophic level and the C produced at a lower level (Dickman et al., 2008; Downing et al., 1990; 
Lindeman, 1942; McNaughton et al., 1989). These transfer efficiencies are not defined as for individual organisms because they consider inputs to a food web and biomass increments in a single component of the food web, but we include them here for completeness. The scale at which $\mathrm{C}$ transfer efficiencies are calculated varies widely, ranging from small-scale laboratory to broad-scale field studies (Fig. 3). In terrestrial systems, where NPP is the main C input to food-webs, the efficiency of herbivore production is evaluated with respect to NPP (McNaughton et al., 1989). In aquatic systems, allochtonous $\mathrm{C}$ inputs have been typically neglected, and the efficiency of herbivore or predator production is also estimated with respect to primary productivity.

\subsection{Soils and sediments}

The efficiency of $\mathrm{C}$ storage in soils has been studied in the context of climate change mitigation strategies, aiming to understand how much of the $\mathrm{C}$ added to a soil can be stored there and potentially sequestered (Stewart et al., 2007). The $\mathrm{C}$ storage efficiency of soils $\left(\mathrm{CSE}_{\text {soil }}\right)$ is defined as the ratio of the net soil $\mathrm{C}$ balance and the total $\mathrm{C}$ inputs from vegetation ( NPP) and soil amendments. As such, $\mathrm{CSE}_{\text {soil }}$ can be positive when soils accumulate C or negative when $\mathrm{C}$ losses are larger than inputs. With this definition, and assuming for simplicity that $\mathrm{NEP} \approx \mathrm{NECB}, \mathrm{CSE}_{\text {soil }}$ can be related to ecosystem and vegetation CUE (Section 1.7) as $\mathrm{CUE}_{\text {ecosystem }} \approx \mathrm{CSE}_{\text {soil }} \times$ $\mathrm{CUE}_{\text {vegetation }}$.

$\mathrm{C}$ fluxes to quantify $\mathrm{CSE}_{\text {soil }}$ are measured at the plot- to field-scale, analogous to $\mathrm{CUE}_{\text {ecosystem, but }}$ because soil organic matter changes slowly, $\mathrm{CSE}_{\text {soil }}$ is generally defined over decades in specifically designed long-term experiments set up in agricultural systems where vertical $\mathrm{C}$ inputs are controlled and manipulated (but again lateral $\mathrm{C}$ fluxes are neglected; see references in Table S2). In these experiments, annual $\mathrm{C}$ inputs are measured and long-term $\mathrm{C}$ storage changes are estimated from repeated SOC measurements - thus, this method implicitly requires a (long) time frame over which a time-integrated CSE is calculated.

A conceptually similar CSE can be defined for lake and marine sediments and is often referred to as organic $\mathrm{C}$ burial efficiency (or preservation efficiency), as the ratio between the rates of $\mathrm{C}$ burial and of deposition at the sediment surface ( $\mathrm{CSE}_{\text {sediment }}$ ) (Alin and Johnson, 2007; Canfield, 1994; Hedges and Keil, 1995). In sediment CSE calculations, benthic photosynthesis is ignored in most environments (despite shallow-water ecosystems being among the most productive in the world), assuming that the export of $\mathrm{C}$ from the photic zone dominates $\mathrm{C}$ accumulation. Organic $\mathrm{C}$ accumulation in sediments is often only measurable over multi-year timescales by ${ }^{210} \mathrm{~Pb}$ dating, which fails to account for the initial rapid degradation of organic material at the sediment surface. As for soils, this method yields a time-integrated CSE (rather than instantaneous). An alternative definition involves primary productivity instead of $\mathrm{C}$ deposition, which underestimates CSE because it neglects C removal via respiration in the photic zone and during sedimentation (Azam and Malfatti, 2007; Ducklow et al.,

140 2001). An instantaneous burial efficiency can be determined by measurements of ${ }^{210} \mathrm{~Pb}$-based $\mathrm{C}$ accumulation rates minus respiration rates measured through oxygen consumption. Moreover, all these methods share similar issues; primarily, they focus on vertical fluxes and tend to neglect lateral transport of C, in particular as DOC (Seiter et al., 2005; Alperin et al., 1994).

\subsection{Ecosystems}

145 At the ecosystem level, both CUE of the biotic components and CSE can be defined. When focusing on the biotic components, the only input $U=$ GPP and the only output is respiration (assuming exudates are re-cycled), which 
comprises autotrophic and heterotrophic terms. Net ecosystem productivity (NEP) is thus defined as the difference between GPP and the total respiration $\left(R=R_{a}+R_{h}\right)$, and ecosystem CUE can be written as,

$$
\mathrm{CUE}_{\text {ecosystem }}=\frac{\text { Net ecosystem productivity }}{\text { Gross primary productivity }}=\frac{\mathrm{NEP}}{\mathrm{GPP}}=1-\frac{R}{\mathrm{GPP}}=1-\frac{R_{a}+R_{h}}{G P P}=\mathrm{CUE}_{\text {plant community }}-\frac{R_{h}}{\mathrm{GPP}},
$$

where the first equality is used for empirical estimation of ecosystem CUE (Fernandez-Martinez et al., 2014), whereas the last equality links ecosystem CUE to the vegetation CUE (=NPP/GPP; Eq. (S3)) and the heterotrophic respiration to GPP ratio. When including abiotic components and thus lateral abiotic fluxes, Eq. (10) in the main text can be used to obtain,

$$
\mathrm{CSE}_{\text {ecosystem }}=1-\frac{R_{a}+R_{h}+F_{\text {out }}}{\mathrm{GPP}+F_{\text {in }}} .
$$

The scale at which terrestrial ecosystem-level $\mathrm{C}$ fluxes are measured is comparable to that for plant communities ( $\sim 100-1000 \mathrm{~m})$, but the control volume extends to include soils (generally down to the rooting depth) (Chapin et al., 2006). C fluxes are generally obtained from eddy covariance systems that measure vertical net $\mathrm{CO}_{2}$ exchanges (NEE); GPP is then inferred by adding total ecosystem respiration (based on night-time C exchanges) to the daytime $\mathrm{C}$ fluxes. While the eddy covariance approach provides fluxes at sub-daily time scales, often these are aggregated at the annual time scale in ecosystem-level CUE and CSE estimates. Because this approach measures vertical $\mathrm{CO}_{2}$ exchanges, it neglects lateral transfer of $\mathrm{C}$ in both the atmosphere and the water bodies (see Sect. 1.8), and exchanges occurring in gaseous forms other than $\mathrm{CO}_{2}$ (Chapin et al., 2006).

In aquatic systems, net oxygen fluxes are often used to infer C fluxes and CUE (Hoellein et al., 2013; Glud, 2008). Measurements are conducted on small samples ( 0.1-1 L), but averaged spatially to have representative values for the water body under investigation, or by eddy covariance (over spatial scales $\sim 100$ $1000 \mathrm{~m}$ ) (Berg et al., 2003). Respiration is calculated from oxygen consumption at night, which is then used to correct the daytime net oxygen production to estimate gross primary productivity. Moreover, as for terrestrial ecosystems, this approach neglects allochthonous $\mathrm{CO}_{2}$ contributions; e.g., from groundwater (Hall and Tank, 2005). Most freshwater bodies are prevalently heterotrophic, because of large allochthonous inputs of organic $C$ that is decomposed locally (Duarte and Prairie, 2005; Hoellein et al., 2013). As a consequence, NEP is often

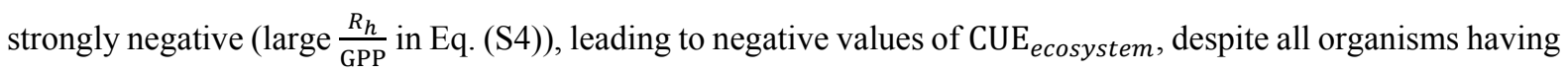
positive CUE values. When accounting for C transport in and out of a heterotrophic system (Eq. (S5)), estimated CSE is expected to increase because $F_{\text {out }}<F_{\text {in }}$, which reduces the numerator with respect to the denominator in the last term of Eq. (S5). As a result, $\mathrm{CSE}_{\text {ecosystem }}>\mathrm{CUE}_{\text {ecosystem }}$, although $\mathrm{CSE}_{\text {ecosystem }}$ remains negative as long as the ecosystem is a net source of $\mathrm{C}$.

In the photic zone of marine ecosystems, a conceptually similar efficiency is defined - the biological pump efficiency, which represents the ratio of $\mathrm{C}$ exported outside the euphotic zone (operationally defined at 100 m depth) over the net primary productivity (Ducklow et al., 2001; Volk and Hoffert, 1985). The biological pump efficiency is estimated from independent measurements of net primary productivity (phytoplankton uptake minus respiration over a 24-hour period) and $\mathrm{C}$ export either from sediment traps or ${ }^{234} \mathrm{Th}$ flux-based measurements (Boyd and Trull, 2007; Giering et al., 2017; Le Moigne et al., 2015). This efficiency increases when less C is remineralized in the euphotic zone via decomposition and consumption by the aquatic food web (Azam and Malfatti, 2007; Ducklow et al., 2001). However, not all C exported below the euphotic zone is stored, because a potentially large fraction is re-mineralized in the upper mesopelagic zone ( $<300 \mathrm{~m}$ water depth) (Buesseler and Boyd, 2009; 
Wakeham et al., 1997). A better measure of C storage efficiency for marine systems is therefore the organic carbon burial efficiency in sediment (Sect. 1.6). However, in particular in shelf systems, resuspension and lateral transport of deposited organic material to the continental slope constitute an important loss component (Inthorn et al., 2006).

Figure S1a illustrates the relations between $\mathrm{C}$ export rates (either as litter production or $\mathrm{C}$ export below the euphotic zone) and net primary productivity in terrestrial and aquatic ecosystems. The ratios of these $\mathrm{C}$ export and NPP fluxes define C export efficiencies (or biological pump efficiency for oceanic systems), shown in Fig. S1b. Terrestrial systems have much higher efficiencies than aquatic systems in general and in particular than oceanic systems $(p<0.05)$, indicating that herbivory or other $\mathrm{C}$ loss pathways are more effective in aquatic systems at removing biomass that would be otherwise exported to the decomposition pathway.

\subsection{Watersheds}

Watersheds represent naturally-defined control volumes for water fluxes and are convenient also for $\mathrm{C}$ budget calculations because they allow measuring lateral outputs of dissolved $\mathrm{C}$ at the watershed outlet. At the watershed scale, $\mathrm{C}$ inputs are given by terrestrial and aquatic GPP and atmospheric deposition (which we neglect for simplicity) and C outputs include heterotrophic and autotrophic respiration (as in Sect. 1.7), but also lateral abiotic losses via dissolved organic and inorganic $\mathrm{C}$ transport in rivers and groundwater (denoted by $F_{\text {out }}$ ). Thanks to the nature of a watershed, $\mathrm{C}$ flows by advection in dissolved phase are limited to losses from the system, so that abiotic $\mathrm{C}$ inputs can be neglected compared the to the other $\mathrm{C}$ fluxes. Therefore, the watershed-scale CSE can be defined as (from Eq. (10) in the main text and the definition of CUE ecosystem in Eq. (S4)),

$$
\mathrm{CSE}_{\text {watershed }}=\frac{\mathrm{NECB}}{\mathrm{GPP}}=1-\frac{R+F_{\text {out }}}{\mathrm{GPP}}=\mathrm{CUE}_{\text {ecosystem }}-\frac{F_{\text {out }}}{\mathrm{GPP}},
$$

where the net ecosystem carbon balance is evaluated in the whole watershed. Eq. (S6) illustrates that increased abiotic losses of $\mathrm{C}$ decrease $\mathrm{CSE}_{\text {watershed }}$ with respect to the efficiency of the biotic component of the system $\left(\mathrm{CUE}_{\text {ecosystem }}\right)$. Also, the lateral abiotic losses are particularly high at times when GPP is low, such as during high precipitation/low radiation events (Öquist et al., 2014) or during snow-melt in cold environments (Finlay et al., 2006). There are only a few watersheds with long-term monitoring of both vegetation-atmosphere $\mathrm{C}$ exchanges and $\mathrm{C}$ transport in water bodies, in which $\mathrm{CSE}_{\text {watershed }}$ can be estimated (see references in Table S2).

\section{References}

Adams, S. M., Kimmel, B. L., and Ploskey, G. R.: Sources of organic-matter for reservoir fish production - A trophic-dynamics analysis, Canadian Journal of Fisheries and Aquatic Sciences, 40, 1480-1495, 10.1139/f83-170, 1983.

210 Alin, S. R., and Johnson, T. C.: Carbon cycling in large lakes of the world: A synthesis of production, burial, and lakeatmosphere exchange estimates, Global Biogeochemical Cycles, 21, 10.1029/2006gb002881, 2007.

Allison, S. D.: Soil minerals and humic acids alter enzyme stability: implications for ecosystem processes, Biogeochemistry, 81, 361-373, 10.1007/s10533-006-9046-2, 2006.

Alperin, M. J., Albert, D. B., and Martens, C. S.: Seasonal-variations in production and consumption rates of dissolved organiccarbon in an organic-rich coastal sediment, Geochimica Et Cosmochimica Acta, 58, 4909-4930, 10.1016/00167037(94)90221-6, 1994.

Atkin, O. K., Botman, B., and Lambers, H.: The causes of inherently slow growth in alpine plants: An analysis based on the underlying carbon economies of alpine and lowland Poa species, Functional Ecology, 10, 698-707, 10.2307/2390504, 1996. 
Atkin, O. K., Scheurwater, I., and Pons, T. L.: Respiration as a percentage of daily photosynthesis in whole plants is homeostatic at moderate, but not high, growth temperatures, New Phytologist, 174, 367-380, 10.1111/j.14698137.2007.02011.x, 2007.

Atkin, O. K., Bloomfield, K. J., Reich, P. B., Tjoelker, M. G., Asner, G. P., Bonal, D., Bonisch, G., Bradford, M. G., Cernusak, L. A., Cosio, E. G., Creek, D., Crous, K. Y., Domingues, T. F., Dukes, J. S., Egerton, J. J. G., Evans, J. R., Farquhar, G. D., Fyllas, N. M., Gauthier, P. P. G., Gloor, E., Gimeno, T. E., Griffin, K. L., Guerrieri, R., Heskel, M. A., Huntingford, C., Ishida, F. Y., Kattge, J., Lambers, H., Liddell, M. J., Lloyd, J., Lusk, C. H., Martin, R. E., Maksimov, A. P., Maximov, T. C., Malhi, Y., Medlyn, B. E., Meir, P., Mercado, L. M., Mirotchnick, N., Ng, D., Niinemets, U., O'Sullivan, O. S., Phillips, O. L., Poorter, L., Poot, P., Prentice, I. C., Salinas, N., Rowland, L. M., Ryan, M. G., Sitch, S., Slot, M., Smith, N. G., Turnbull, M. H., VanderWel, M. C., Valladares, F., Veneklaas, E. J., Weerasinghe, L. K., Wirth, C., Wright, I. J., Wythers, K. R., Xiang, J., Xiang, S., and Zaragoza-Castells, J.: Global variability in leaf respiration in relation to climate, plant functional types and leaf traits, New Phytologist, 206, 614-636, 10.1111/nph.13253, 2015.

Azam, F., and Malfatti, F.: Microbial structuring of marine ecosystems, Nature Reviews Microbiology, 5, 782-791, 10.1038/nrmicro1747, 2007.

Beer, C., Reichstein, M., Tomelleri, E., Ciais, P., Jung, M., Carvalhais, N., Rodenbeck, C., Arain, M. A., Baldocchi, D., Bonan, G. B., Bondeau, A., Cescatti, A., Lasslop, G., Lindroth, A., Lomas, M., Luyssaert, S., Margolis, H., Oleson, K. W., Roupsard,

O., Veenendaal, E., Viovy, N., Williams, C., Woodward, F. I., and Papale, D.: Terrestrial Gross Carbon Dioxide Uptake: Global Distribution and Covariation with Climate, Science, 329, 834-838, 10.1126/science.1184984, 2010.

Berg, P., Roy, H., Janssen, F., Meyer, V., Jorgensen, B. B., Huettel, M., and de Beer, D.: Oxygen uptake by aquatic sediments measured with a novel non-invasive eddy-correlation technique, Marine Ecology Progress Series, 261, 75-83, 10.3354/meps261075, 2003.

240 Bolscher, T., Paterson, E., Freitag, T., Thornton, B., and Herrmann, A. M.: Temperature sensitivity of substrate-use efficiency can result from altered microbial physiology without change to community composition, Soil Biology \& Biochemistry, 109, 59-69, 10.1016/j.soilbio.2017.02.005, 2017.

Boyd, P. W., and Trull, T. W.: Understanding the export of biogenic particles in oceanic waters: Is there consensus?, Progress in Oceanography, 72, 276-312, 10.1016/j.pocean.2006.10.007, 2007.

245 Brostoff, W. N., Sharifi, M. R., and Rundel, P. W.: Photosynthesis of cryptobiotic crusts in a seasonally inundated system of pans and dunes at Edwards Air Force Base, western Mojave Desert, California: Laboratory studies, Flora, 197, 143-151, 10.1078/0367-2530-00024, 2002.

Brostoff, W. N., Sharifi, M. R., and Rundel, P. W.: Photosynthesis of cryptobiotic soil crusts in a seasonally inundated system of pans and dunes in the western Mojave Desert, CA: Field studies, Flora, 200, 592-600, 10.1016/j.flora.2005.06.008, 2005.

Büdel, B., Vivas, M., and Lange, O. L.: Lichen species dominance and the resulting photosynthetic behavior of Sonoran Desert soil crust types (Baja California, Mexico), Ecological Processes, 2, 6, 10.1186/2192-1709-2-6, 2013.

Buesseler, K. O., and Boyd, P. W.: Shedding light on processes that control particle export and flux attenuation in the twilight zone of the open ocean, Limnology and Oceanography, 54, 1210-1232, 10.4319/1o.2009.54.4.1210, 2009.

Campioli, M., Vicca, S., Luyssaert, S., Bilcke, J., Ceschia, E., Chapin Iii, F. S., Ciais, P., Fernandez-Martinez, M., Malhi, Y.,

Obersteiner, M., Olefeldt, D., Papale, D., Piao, S. L., Penuelas, J., Sullivan, P. F., Wang, X., Zenone, T., and Janssens, I. A.: Biomass production efficiency controlled by management in temperate and boreal ecosystems, Nature Geosci, 8, 843-846, $10.1038 /$ ngeo2553, 2015

Canfield, D. E.: Factors influencing organic-carbon preservation in marine-sediments, Chemical Geology, 114, 315-329, 10.1016/0009-2541(94)90061-2, 1994.

260 Cannell, M. G. R., and Thornley, J. H. M.: Modelling the components of plant respiration: Some guiding principles, Annals of Botany, 85, 45-54, 2000.

Cebrian, J., and Lartigue, J.: Patterns of herbivory and decomposition in aquatic and terrestrial ecosystems, Ecological Monographs, 74, 237-259, 2004. 
Chapin, F. S., Woodwell, G. M., Randerson, J. T., Rastetter, E. B., Lovett, G. M., Baldocchi, D. D., Clark, D. A., Harmon, M. E., Schimel, D. S., Valentini, R., Wirth, C., Aber, J. D., Cole, J. J., Goulden, M. L., Harden, J. W., Heimann, M., Howarth, R. W., Matson, P. A., McGuire, A. D., Melillo, J. M., Mooney, H. A., Neff, J. C., Houghton, R. A., Pace, M. L., Ryan, M. G., Running, S. W., Sala, O. E., Schlesinger, W. H., and Schulze, E. D.: Reconciling carbon-cycle concepts, terminology, and methods, Ecosystems, 9, 1041-1050, 10.1007/s10021-005-0105-7, 2006.

Clark, D. A., Brown, S., Kicklighter, D. W., Chambers, J. Q., Thomlinson, J. R., and Ni, J.: Measuring net primary production in forests: Concepts and field methods, Ecological Applications, 11, 356-370, 2001.

Collado, S., Rosas, I., Gonzalez, E., Gutierrez-Lavin, A., and Diaz, M.: Pseudomonas putida response in membrane bioreactors under salicylic acid-induced stress conditions, Journal of Hazardous Materials, 267, 9-16, 10.1016/j.jhazmat.2013.12.034, 2014.

del Giorgio, P. A., and Cole, J. J.: Bacterial growth efficiency in natural aquatic systems, Annual Review of Ecology and Systematics, 29, 503-541, 1998.

DeLucia, E. H., Drake, J. E., Thomas, R. B., and Gonzalez-Meler, M.: Forest carbon use efficiency: is respiration a constant fraction of gross primary production?, Global Change Biology, 13, 1157-1167, 10.1111/j.1365-2486.2007.01365.x, 2007.

Dickman, E. M., Newell, J. M., Gonzalez, M. J., and Vanni, M. J.: Light, nutrients, and food-chain length constrain planktonic energy transfer efficiency across multiple trophic levels, Proceedings of the National Academy of Sciences of the United States of America, 105, 18408-18412, 10.1073/pnas.0805566105, 2008.

Dillaway, D. N., and Kruger, E. L.: Trends in seedling growth and carbon-use efficiency vary among broadleaf tree species along a latitudinal transect in eastern North America, Global Change Biology, 20, 908-922, 2014.

Dinsmore, K. J., Billett, M. F., Skiba, U. M., Rees, R. M., Drewer, J., and Helfter, C.: Role of the aquatic pathway in the carbon and greenhouse gas budgets of a peatland catchment, Global Change Biology, 16, 2750-2762, 10.1111/j.13652486.2009.02119.x, 2010.

Downing, J. A., Plante, C., and Lalonde, S.: Fish production correlated with primary productivity, not the morphoedaphic index, Canadian Journal of Fisheries and Aquatic Sciences, 47, 1929-1936, 10.1139/f90-217, 1990.

Duarte, C. M., and Prairie, Y. T.: Prevalence of heterotrophy and atmospheric CO2 emissions from aquatic ecosystems, Ecosystems, 8, 862-870, 10.1007/s10021-005-0177-4, 2005.

290 Ducklow, H. W., Steinberg, D. K., and Buesseler, K. O.: Upper ocean carbon export and the biological pump, Oceanography, 14, 50-58, 2001.

Dunne, J. P., Armstrong, R. A., Gnanadesikan, A., and Sarmiento, J. L.: Empirical and mechanistic models for the particle export ratio, Global Biogeochemical Cycles, 19, 10.1029/2004gb002390, 2005.

Ferland, M. E., Prairie, Y. T., Teodoru, C., and del Giorgio, P. A.: Linking organic carbon sedimentation, burial efficiency, and long-term accumulation in boreal lakes, Journal of Geophysical Research-Biogeosciences, 119, 836-847, 10.1002/2013jg002345, 2014.

Fernandez-Martinez, M., Vicca, S., Janssens, I. A., Sardans, J., Luyssaert, S., Campioli, M., Chapin Iii, F. S., Ciais, P., Malhi, Y., Obersteiner, M., Papale, D., Piao, S. L., Reichstein, M., Roda, F., and Penuelas, J.: Nutrient availability as the key regulator of global forest carbon balance, Nature Clim. Change, 4, 471-476, 10.1038/nclimate2177, 2014.

300 Finlay, J., Neff, J., Zimov, S., Davydova, A., and Davydov, S.: Snowmelt dominance of dissolved organic carbon in highlatitude watersheds: Implications for characterization and flux of river DOC, Geophysical Research Letters, 33, 10.1029/2006gl025754, 2006.

Frantz, J. M., Cometti, N. N., and Bugbee, B.: Night temperature has a minimal effect on respiration and growth in rapidly growing plants, Annals of Botany, 94, 155-166, 10.1093/aob/mch122, 2004.

305 Frantz, J. M., and Bugbee, B.: Acclimation of plant populations to shade: Photosynthesis, respiration, and carbon use efficiency, Journal of the American Society for Horticultural Science, 130, 918-927, 2005.

Frey, S. D., Lee, J., Melillo, J. M., and Six, J.: The temperature response of soil microbial efficiency and its feedback to climate, Nature Clim. Change, 3, 395-398, 10.1038/nclimate1796, 2013. 
Geyer, K. M., Kyker-Snowman, E., Grandy, A. S., and Frey, S. D.: Microbial carbon use efficiency: accounting for population, community, and ecosystem-scale controls over the fate of metabolized organic matter, Biogeochemistry, 127, 173-188, 10.1007/s10533-016-0191-y, 2016.

Gielen, B., Neirynck, J., Luyssaert, S., and Janssens, I. A.: The importance of dissolved organic carbon fluxes for the carbon balance of a temperate Scots pine forest, Agricultural and Forest Meteorology, 151, 270-278, 10.1016/j.agrformet.2010.10.012, 2011.

315 Giering, S. L. C., Sanders, R., Martin, A. P., Henson, S. A., Riley, J. S., Marsay, C. M., and Johns, D. G.: Particle flux in the oceans: Challenging the steady state assumption, Global Biogeochemical Cycles, 31, 159-171, 10.1002/2016gb005424, 2017. Gifford, R. M.: Whole plant respiration and photosynthesis of wheat under increased $\mathrm{CO} 2$ concentration and temperature: Long-term vs short-term distinctions for modelling, Global Change Biology, 1, 385-396, 10.1111/j.13652486.1995.tb00037.x, 1995

320 Gifford, R. M.: Plant respiration in productivity models: conceptualisation, representation and issues for global terrestrial carbon-cycle research, Functional Plant Biology, 30, 171-186, 10.1071/fp02083, 2003.

Glud, R. N.: Oxygen dynamics of marine sediments, Marine Biology Research, 4, 243-289, 10.1080/17451000801888726, 2008.

Gommers, P. J. F., Vanschie, B. J., Vandijken, J. P., and Kuenen, J. G.: Biochemical limits to microbial-growth yields. An analysis of mixed substrate utilization, Biotechnology and Bioengineering, 32, 86-94, 10.1002/bit.260320112, 1988.

Goulden, M. L., and Crill, P. M.: Automated measurements of $\mathrm{CO} 2$ exchange at the moss surface of a black spruce forest, Tree Physiology, 17, 537-542, 1997.

Green, T. G. A., Schroeter, B., Kappen, L., Seppelt, R. D., and Maseyk, K.: An assessment of the relationship between chlorophyll a fluorescence and $\mathrm{CO} 2$ gas exchange from field measurements on a moss and lichen, Planta, 206, 611-618, $10.1007 / \mathrm{s} 004250050439,1998$.

Hall, R. O., and Tank, J. L.: Correcting whole-stream estimates of metabolism for groundwater input, Limnology and Oceanography-Methods, 3, 222-229, 10.4319/lom.2005.3.222, 2005.

Hartnett, H. E., Keil, R. G., Hedges, J. I., and Devol, A. H.: Influence of oxygen exposure time on organic carbon preservation in continental margin sediments, Nature, 391, 572-574, 10.1038/35351, 1998.

335 Hedges, J. I., and Keil, R. G.: Sedimentary organic matter preservation: an assessment and speculative synthesis, Marine Chemistry, 49, 81-115, https://doi.org/10.1016/0304-4203(95)00008-F, 1995.

Helfter, C., Campbell, C., Dinsmore, K. J., Drewer, J., Coyle, M., Anderson, M., Skiba, U., Nemitz, E., Billett, M. F., and Sutton, M. A.: Drivers of long-term variability in $\mathrm{CO} 2$ net ecosystem exchange in a temperate peatland, Biogeosciences, 12 , 1799-1811, 10.5194/bg-12-1799-2015, 2015.

340 Hoellein, T. J., Bruesewitz, D. A., and Richardson, D. C.: Revisiting Odum (1956): A synthesis of aquatic ecosystem metabolism, Limnology and Oceanography, 58, 2089-2100, 10.4319/1o.2013.58.6.2089, 2013.

Hua, K. K., Wang, D. Z., Guo, X. S., and Guo, Z. B.: Carbon Sequestration Efficiency of Organic Amendments in a LongTerm Experiment on a Vertisol in Huang-Huai-Hai Plain, China, Plos One, 9, 10.1371/journal.pone.0108594, 2014.

Inthorn, M., Wagner, T., Scheeder, G., and Zabel, M.: Lateral transport controls distribution, quality, and burial of organic matter along continental slopes in high-productivity areas, Geology, 34, 205-208, 10.1130/g22153.1, 2006.

Iverson, R. L.: Control of marine fish production, Limnology and Oceanography, 35, 1593-1604, 1990.

Jeffries, D. L., Link, S. O., and Klopatek, J. M.: CO2 fluxes of cryptogamic crusts. 1. Response to resaturation, New Phytologist, 125, 163-173, 10.1111/j.1469-8137.1993.tb03874.x, 1993.

Kappen, L., Lewis Smith, R. I., and Meyer, M.: Carbon Dioxide Exchange of Two Ecodemes of Schistidium antarctici in Continental Antarctica, Polar Biology, 9, 415-422, 1989.

Ladd, J. N., Jocteurmonrozier, L., and Amato, M.: Carbon turnover and nitrogen transformations in an alfisol and vertisol amended with ${ }^{14} \mathrm{C}[\mathrm{U}]$ glucose and ${ }^{15} \mathrm{~N}$ ammonium sulfate, Soil Biology \& Biochemistry, 24, 359-371, 10.1016/00380717(92)90196-5, 1992. 
Lange, O. L., Geiger, I. L., and Schulze, E. D.: Ecophysiological investigations on lichens of Negev Desert. 5. Model to simulate net photosynthesis and respiration of Ramalina-maciformis, Oecologia, 28, 247-259, 1977.

Lange, O. L., Kidron, G. J., Budel, B., Meyer, A., Kilian, E., and Abeliovich, A.: Taxonomic composition and photosynthetic characteristics of the biological soil crusts covering sand dunes in the western Negev desert, Functional Ecology, 6, 519-527, 10.2307/2390048, 1992.

Lange, O. L., Budel, B., Meyer, A., and Kilian, E.: Further evidence that activation of net photosynthesis by dry cyanobacterial lichens requires liquid water, Lichenologist, 25, 175-189, 1993.

Lange, O. L., Belnap, J., Reichenberger, H., and Meyer, A.: Photosynthesis of green algal soil crust lichens from arid lands in southern Utah, USA: Role of water content on light and temperature responses of CO2 exchange, Flora, 192, 1-15, 1997a.

Lange, O. L., Green, T. G. A., Reichenberger, H., Hesbacher, S., and Proksch, P.: Do secondary substances in the thallus of a lichen promote $\mathrm{CO} 2$ diffusion and prevent depression of net photosynthesis at high water content?, Oecologia, 112, 1-3, 10.1007/s004420050275, $1997 \mathrm{~b}$.

Lange, O. L., Belnap, J., and Reichenberger, H.: Photosynthesis of the Cyanobacterial soil-crust lichen Collema tenax from arid lands in southern Utah, USA: role of water content on light and temperature responses of $\mathrm{CO}(2)$ exchange, Functional Ecology, 12, 195-202, 10.1046/j.1365-2435.1998.00192.x, 1998.

Lange, O. L., Budel, B., Meyer, A., Zellner, H., and Zotz, G.: Lichen carbon gain under tropical conditions: water relations and CO2 exchange of three Leptogium species of a lower montane rainforest in Panama, Flora, 195, 172-190, 2000.

Lange, O. L.: Photosynthetic productivity of the epilithic lichen Lecanora muralis: Long-term field monitoring of $\mathrm{CO} 2$ exchange and its physiological interpretation - I. Dependence of photosynthesis on water content, light, temperature, and CO2 concentration from laboratory measurements, Flora, 197, 233-249, 10.1078/0367-2530-00038, 2002.

Lange, O. L., and Green, T. A.: Photosynthetic performance of a foliose lichen of biological soil-crust communities: long-term monitoring of the $\mathrm{CO} 2$ exchange of Cladonia convoluta under temperate habitat conditions, Bibliotheca Lichenologica, 86, 257-280, 2002.

Lange, O. L., Budel, B., Meyer, A., Zellner, H., and Zotz, G.: Lichen carbon gain under tropical conditions: water relations and $\mathrm{CO} 2$ exchange of Lobariaceae species of a lower montane rainforest in Panama, Lichenologist, 36, 329-342, 10.1017/s0024282904014392, 2004.

380 Lange, O. L., and Green, T. A.: Photosynthetic performance of the squamulose soil-crust lichen Squamarina lentigera: laboratory measurements and long-term monitoring of $\mathrm{CO} 2$ exchange in the field, Bibliotheca Lichenologica, 88, 363-392, 2004.

Lange, O. L., Green, T. G. A., Melzer, B., Meyer, A., and Zellner, H.: Water relations and CO2 exchange of the terrestrial lichen Teloschistes capensis in the Namib fog desert: Measurements during two seasons in the field and under controlled conditions, Flora, 201, 268-280, 10.1016/j.flora.2005.08.003, 2006.

Lasslop, G., Reichstein, M., Papale, D., Richardson, A. D., Arneth, A., Barr, A., Stoy, P., and Wohlfahrt, G.: Separation of net ecosystem exchange into assimilation and respiration using a light response curve approach: critical issues and global evaluation, Global Change Biology, 16, 187-208, 10.1111/j.1365-2486.2009.02041.x, 2010.

Le Moigne, F. A. C., Poulton, A. J., Henson, S. A., Daniels, C. J., Fragoso, G. M., Mitchell, E., Richier, S., Russell, B. C.,

Smith, H. E. K., Tarling, G. A., Young, J. R., and Zubkov, M.: Carbon export efficiency and phytoplankton community composition in the Atlantic sector of the Arctic Ocean, Journal of Geophysical Research-Oceans, 120, 3896-3912, 10.1002/2015jc010700, 2015.

Leach, J. A., Larsson, A., Wallin, M. B., Nilsson, M. B., and Laudon, H.: Twelveyear interannual and seasonal variability of stream carbon export from a boreal peatland catchment, Journal of Geophysical Research-Biogeosciences, 121, 1851-1866, 10.1002/2016jg003357, 2016.

Lefebure, R., Degerman, R., Andersson, A., Larsson, S., Eriksson, L. O., Bamstedt, U., and Bystrom, P.: Impacts of elevated terrestrial nutrient loads and temperature on pelagic food-web efficiency and fish production, Global Change Biology, 19, 1358-1372, 10.1111/gcb.12134, 2013. 
Lehmeier, C. A., Ballantyne, F., Min, K., and Billings, S. A.: Temperature-mediated changes in microbial carbon use efficiency and C-13 discrimination, Biogeosciences, 13, 3319-3329, 10.5194/bg-13-3319-2016, 2016.

Lenhart, K., Weber, B., Elbert, W., Steinkamp, J., Clough, T., Crutzen, P., Poschl, U., and Keppler, F.: Nitrous oxide and methane emissions from cryptogamic covers, Global Change Biology, 21, 3889-3900, 10.1111/gcb.12995, 2015.

Liang, F., Li, J. W., Yang, X. Y., Huang, S. M., Cai, Z. J., Gao, H. J., Ma, J. Y., Cui, X., and Xu, M. G.: Three-decade long fertilization-induced soil organic carbon sequestration depends on edaphic characteristics in six typical croplands, Scientific Reports, 6, 10.1038/srep30350, 2016.

Liang, Y., Melack, J. M., and Wang, J.: Primary production and fish yields in Chinese ponds and lakes, Transactions of the American Fisheries Society, 110, 346-350, 10.1577/1548-8659(1981)110<346:ppafyi>2.0.co;2, 1981.

Lindeman, R. L.: The Trophic-Dynamic Aspect of Ecology, Ecology, 23, 399-417, 10.2307/1930126, 1942.

Lotscher, M., Klumpp, K., and Schnyder, H.: Growth and maintenance respiration for individual plants in hierarchically structured canopies of Medicago sativa and Helianthus annuus: the contribution of current and old assimilates, New Phytologist, 164, 305-316, 10.1111/j.1469-8137.2004.01170.x, 2004.

Loveys, B. R., Scheurwater, I., Pons, T. L., Fitter, A. H., and Atkin, O. K.: Growth temperature influences the underlying components of relative growth rate: an investigation using inherently fast- and slow-growing plant species, Plant Cell and Environment, 25, 975-987, 10.1046/j.1365-3040.2002.00879.x, 2002.

415 Luyssaert, S., Inglima, I., Jung, M., Richardson, A. D., Reichstein, M., Papale, D., Piao, S. L., Schulzes, E. D., Wingate, L., Matteucci, G., Aragao, L., Aubinet, M., Beers, C., Bernhofer, C., Black, K. G., Bonal, D., Bonnefond, J. M., Chambers, J., Ciais, P., Cook, B., Davis, K. J., Dolman, A. J., Gielen, B., Goulden, M., Grace, J., Granier, A., Grelle, A., Griffis, T., Grunwald, T., Guidolotti, G., Hanson, P. J., Harding, R., Hollinger, D. Y., Hutyra, L. R., Kolar, P., Kruijt, B., Kutsch, W., Lagergren, F., Laurila, T., Law, B. E., Le Maire, G., Lindroth, A., Loustau, D., Malhi, Y., Mateus, J., Migliavacca, M., Misson,

420 L., Montagnani, L., Moncrieff, J., Moors, E., Munger, J. W., Nikinmaa, E., Ollinger, S. V., Pita, G., Rebmann, C., Roupsard, O., Saigusa, N., Sanz, M. J., Seufert, G., Sierra, C., Smith, M. L., Tang, J., Valentini, R., Vesala, T., and Janssens, I. A.: CO2 balance of boreal, temperate, and tropical forests derived from a global database, Global Change Biology, 13, 2509-2537, 10.1111/j.1365-2486.2007.01439.x, 2007.

Luyssaert, S., Inglima, I., and Jung, M.: Global Forest Ecosystem Structure and Function Data For Carbon Balance Research. ORNL DAAC, Oak Ridge, Tennessee, USA, 2009.

Manzoni, S., Taylor, P. G., Richter, A., Porporato, A., and Ågren, G. I.: Environmental and stoichiometric controls on microbial carbon-use efficiency in soils, New Phytologist, 196, 79-91, 10.1111/j.1469-8137.2012.04225.x, 2012.

Manzoni, S., Čapek, P., Mooshammer, M., Lindahl, B. D., Richter, A., and Šantrůčková, H.: Optimal metabolic regulation along resource stoichiometry gradients, Ecology Letters, 20, 1182-1191, 10.1111/ele.12815, 2017.

430 Marchus, K. A., Blankinship, J. C., and Schimel, J. P.: Environmental controls on extracellular polysaccharide accumulation in a California grassland soil, Soil Biology and Biochemistry, 125, 86-92, https://doi.org/10.1016/j.soilbio.2018.07.009, 2018. McNaughton, S. J., Oesterheld, M., Frank, D. A., and Williams, K. J.: Ecosystem-Level Patterns of Primary Productivity and Herbivory in Terrestrial Habitats, Nature, 341, 142-144, 1989.

Min, K., Lehmeier, C. A., Ballantyne, F., and Billings, S. A.: Carbon Availability Modifies Temperature Responses of

Heterotrophic Microbial Respiration, Carbon Uptake Affinity, and Stable Carbon Isotope Discrimination, Frontiers in Microbiology, 7, 10.3389/fmicb.2016.02083, 2016.

Nemali, K. S., and van Iersel, M. W.: Light effects on wax begonia: Photosynthesis, growth respiration, maintenance respiration, and carbon use efficiency, Journal of the American Society for Horticultural Science, 129, 416-424, 2004.

Oechel, W. C., and Collins, N. J.: Comparative CO2 exchange patterns in mosses from two tundra habitats at Barrow, Alaska,

Canadian Journal of Botany, 54, 1355-1369, 1976.

Olefeldt, D., Roulet, N. T., Bergeron, O., Crill, P., Backstrand, K., and Christensen, T. R.: Net carbon accumulation of a highlatitude permafrost palsa mire similar to permafrost-free peatlands, Geophysical Research Letters, 39, 10.1029/2011 g1050355, 2012. 
Öquist, M. G., Bishop, K., Grelle, A., Klemedtsson, L., Kohler, S. J., Laudon, H., Lindroth, A., Lofvenius, M. O., Wallin, M. B., and Nilsson, M. B.: The Full Annual Carbon Balance of Boreal Forests Is Highly Sensitive to Precipitation, Environmental Science \& Technology Letters, 1, 315-319, 10.1021/ez500169j, 2014.

Öquist, M. G., Erhagen, B., Haei, M., Sparrman, T., Ilstedt, U., Schleucher, J., and Nilsson, M. B.: The effect of temperature and substrate quality on the carbon use efficiency of saprotrophic decomposition, Plant and Soil, 414, 113-125, 10.1007/s11104-016-3104-x, 2017.

450 Palmqvist, K., and Sundberg, B.: Light use efficiency of dry matter gain in five macro-lichens: relative impact of microclimate conditions and species-specific traits, Plant Cell and Environment, 23, 1-14, 10.1046/j.1365-3040.2000.00529.x, 2000.

Palmqvist, K.: Cyanolichens: carbon metabolism, in: Cyanobacteria in Symbiosis, edited by: Rai, A. N., Bergman, B., and Rasmussen, U., Kluwer Academis Publishers, Netherlands, 73-96, 2002.

Pannewitz, S., Green, T. G. A., Maysek, K., Schlensog, M., Seppelt, R., Sancho, L. G., Turk, R., and Schroeter, B.: Photosynthetic responses of three common mosses from continental Antarctica, Antarctic Science, 17, 341-352, 10.1017/s0954102005002774, 2005.

Parton, W. J., and Rasmussen, P. E.: Long-Term Effects of Crop Management in Wheat-Fallow .2. Century Model Simulations, Soil Science Society of America Journal, 58, 530-536, 1994.

Paustian, K., Parton, W. J., and Persson, J.: Modeling Soil Organic-Matter in Organic-Amended and Nitrogen-Fertilized LongTerm Plots, Soil Science Society of America Journal, 56, 476-488, 1992.

Peichl, M., Oquist, M., Lofvenius, M. O., Ilstedt, U., Sagerfors, J., Grelle, A., Lindroth, A., and Nilsson, M. B.: A 12-year record reveals pre-growing season temperature and water table level threshold effects on the net carbon dioxide exchange in a boreal fen, Environmental Research Letters, 9, 10.1088/1748-9326/9/5/055006, 2014.

Poeplau, C., Reiter, L., Berti, A., and Kätterer, T.: Qualitative and quantitative response of soil organic carbon to 40 years of

crop residue incorporation under contrasting nitrogen fertilisation regimes, Soil Research, 55, 1-9, https://doi.org/10.1071/SR15377, 2017.

Poffenbarger, H. J., Barker, D. W., Helmers, M. J., Miguez, F. E., Olk, D. C., Sawyer, J. E., Six, J., and Castellano, M. J.: Maximum soil organic carbon storage in Midwest U.S. cropping systems when crops are optimally nitrogen-fertilized, PLOS ONE, 12, e0172293, 10.1371/journal.pone.0172293, 2017.

470 Poorter, H., Remkes, C., and Lambers, H.: Carbon and Nitrogen Economy of 24 Wild-Species Differing in Relative GrowthRate, Plant Physiology, 94, 621-627, 1990.

Porada, P., Weber, B., Elbert, W., Poschl, U., and Kleidon, A.: Estimating global carbon uptake by lichens and bryophytes with a process-based model, Biogeosciences, 10, 6989-7033, 10.5194/bg-10-6989-2013, 2013.

Purakayastha, T. J., Rudrappa, L., Singh, D., Swarup, A., and Bhadraray, S.: Long-term impact of fertilizers on soil organic carbon pools and sequestration rates in maize-wheat.-cowpea cropping system, Geoderma, 144, 370-378, 10.1016/j.geoderma.2007.12.006, 2008.

Reichstein, M., Falge, E., Baldocchi, D., Papale, D., Aubinet, M., Berbigier, P., Bernhofer, C., Buchmann, N., Gilmanov, T., Granier, A., Grunwald, T., Havrankova, K., Ilvesniemi, H., Janous, D., Knohl, A., Laurila, T., Lohila, A., Loustau, D., Matteucci, G., Meyers, T., Miglietta, F., Ourcival, J. M., Pumpanen, J., Rambal, S., Rotenberg, E., Sanz, M., Tenhunen, J.,

Seufert, G., Vaccari, F., Vesala, T., Yakir, D., and Valentini, R.: On the separation of net ecosystem exchange into assimilation and ecosystem respiration: review and improved algorithm, Global Change Biology, 11, 1424-1439, 10.1111/j.13652486.2005.001002.x, 2005.

Rock, A. M., Hall, M. R., Vanni, M. J., and Gonzalez, M. J.: Carnivore identity mediates the effects of light and nutrients on aquatic food-chain efficiency, Freshwater Biology, 61, 1492-1508, 10.1111/fwb.12790, 2016.

485 Roels, J. A.: Application of Macroscopic Principles to Microbial-Metabolism, Biotechnology and Bioengineering, 22, 24572514, 1980.

Rowland, F. E., Bricker, K. J., Mara, M. J. V., and Gonzalez, M. J.: Light and nutrients regulate energy transfer through benthic and pelagic food chains, Oikos, 124, 1648-1663, 10.1111/oik.02106, 2015. 
Šantrůčková, H., Picek, T., Tykva, R., Šimek, M., and Pavlů, B.: Short-term partitioning of C-14- U -glucose in the soil microbial pool under varied aeration status, Biology and Fertility of Soils, 40, 386-392, 10.1007/s00374-004-0790-y, 2004.

Schmidt, R. A., Wiebe, M. G., and Eriksen, N. T.: Heterotrophic high cell-density fed-batch cultures of the phycocyaninproducing red alga Galdieria sulphuraria, Biotechnology and Bioengineering, 90, 77-84, 10.1002/bit.20417, 2005.

Seiter, K., Hensen, C., and Zabel, M.: Benthic carbon mineralization on a global scale, Global Biogeochemical Cycles, 19 , 10.1029/2004gb002225, 2005.

495 Sinsabaugh, R. L., Manzoni, S., Moorhead, D. L., and Richter, A.: Carbon use efficiency of microbial communities: stoichiometry, methodology and modelling, Ecology Letters, 16, 930-939, 10.1111/ele.12113, 2013.

Slansky, F., and Feeny, P.: Stabilization of Rate of Nitrogen Accumulation by Larvae of Cabbage Butterfly on Wild and Cultivated Food Plants, Ecological Monographs, 47, 209-228, 1977.

Sobek, S., Durisch-Kaiser, E., Zurbrugg, R., Wongfun, N., Wessels, M., Pasche, N., and Wehrli, B.: Organic carbon burial efficiency in lake sediments controlled by oxygen exposure time and sediment source, Limnology and Oceanography, 54, 2243-2254, 10.4319/10.2009.54.6.2243, 2009.

Stewart, C. E., Paustian, K., Conant, R. T., Plante, A. F., and Six, J.: Soil carbon saturation: concept, evidence and evaluation, Biogeochemistry, 86, 19-31, 2007.

Street, L. E.: Carbon dynamics in Arctic vegetation, University of Edinburgh, Edinburgh, 2011.

505 Street, L. E., Subke, J. A., Sommerkorn, M., Sloan, V., Ducrotoy, H., Phoenix, G. K., and Williams, M.: The role of mosses in carbon uptake and partitioning in arctic vegetation, New Phytologist, 199, 163-175, 10.1111/nph.12285, 2013.

Sundberg, B., Palmqvist, K., Esseen, P. A., and Renhorn, K. E.: Growth and vitality of epiphytic lichens .2. Modelling of carbon gain using field and laboratory data, Oecologia, 109, 10-18, 10.1007/s004420050052, 1997.

Swanson, R. V., and Flanagan, L. B.: Environmental regulation of carbon dioxide exchange at the forest floor in a boreal black 510 spruce ecosystem, Agricultural and Forest Meteorology, 108, 165-181, 10.1016/s0168-1923(01)00243-x, 2001.

Tan, B. C., Fan, J. B., He, Y. Q., Luo, S. M., and Peng, X. H.: Possible effect of soil organic carbon on its own turnover: A negative feedback, Soil Biology \& Biochemistry, 69, 313-319, 10.1016/j.soilbio.2013.11.017, 2014.

Tcherkez, G., Gauthier, P., Buckley, T. N., Busch, F. A., Barbour, M. M., Bruhn, D., Heskel, M. A., Gong, X. Y., Crous, K. Y., Griffin, K., Way, D., Turnbull, M., Adams, M. A., Atkin, O. K., Farquhar, G. D., and Cornic, G.: Leaf day respiration: low 515 CO2 flux but high significance for metabolism and carbon balance, New Phytologist, 216, 986-1001, 10.1111/nph.14816, 2017.

Tjoelker, M. G., Oleksyn, J., and Reich, P. B.: Acclimation of respiration to temperature and $\mathrm{CO} 2$ in seedlings of boreal tree species in relation to plant size and relative growth rate, Global Change Biology, 5, 679-691, 10.1046/j.13652486.1999.00257.x, 1999.

520 Tretiach, M., and Geletti, A.: CO2 exchange of the endolithic lichen Verrucaria baldensis from karst habitats in northern Italy, Oecologia, 111, 515-522, 10.1007/s004420050265, 1997.

Tum, M., Zeidler, J. N., Gunther, K. P., and Esch, T.: Global NPP and straw bioenergy trends for 2000-2014, Biomass \& Bioenergy, 90, 230-236, 10.1016/j.biombioe.2016.03.040, 2016.

Turetsky, M. R., Mack, M. C., Hollingsworth, T. N., and Harden, J. W.: The role of mosses in ecosystem succession and function in Alaska's boreal forest, Canadian Journal of Forest Research-Revue Canadienne De Recherche Forestiere, 40, 1237 1264, 10.1139/x10-072, 2010.

Uchida, M., Muraoka, H., Nakatsubo, T., Bekku, Y., Ueno, T., Kanda, H., and Koizumi, H.: Net photosynthesis, respiration, and production of the moss Sanionia uncinata on a glacier foreland in the High Arctic, Ny-Alesund, Svalbard, Arctic Antarctic and Alpine Research, 34, 287-292, 10.2307/1552486, 2002.

530 Uchida, M., Nakatsubo, T., Kanda, H., and Koizumi, H.: Estimation of the annual primary production of the lichen Cetrariella delisei in a glacier foreland in the High Arctic, Ny-Alesund, Svalbard, Polar Research, 25, 39-49, 10.1111/j.17518369.2006.tb00149.x, 2006. 
van Iersel, M. W.: Growth and maintenance respiration of Catharanthus roseus L-estimated from CO2 exchange, in: Proceedings of the Xxv International Horticultural Congress, Pt 9: Computers and Automation Electronic Information in Horticulture, edited by: Challa, H., and Monteiro, A. A., Acta Horticulturae, 519, 133-140, 2000.

Van Iersel, M. W.: Carbon use efficiency depends on growth respiration, maintenance respiration, and relative growth rate. A case study with lettuce, Plant Cell and Environment, 26, 1441-1449, 10.1046/j.0016-8025.2003.01067.x, 2003.

Vicca, S., Luyssaert, S., Penuelas, J., Campioli, M., Chapin, F. S., III, Ciais, P., Heinemeyer, A., Hogberg, P., Kutsch, W. L., Law, B. E., Malhi, Y., Papale, D., Piao, S. L., Reichstein, M., Schulze, E. D., and Janssens, I. A.: Fertile forests produce 540 biomass more efficiently, Ecology Letters, 15, 520-526, 10.1111/j.1461-0248.2012.01775.x, 2012.

Volk, T., and Hoffert, M. I.: Ocean Carbon Pumps: Analysis of Relative Strengths and Efficiencies in Ocean-Driven Atmospheric CO2 Changes, in: The Carbon Cycle and Atmospheric CO2: Natural Variations Archean to Present, American Geophysical Union, 99-110, 1985.

Waddington, J. M., and Roulet, N. T.: Carbon balance of a boreal patterned peatland, Global Change Biology, 6, 87-97, 545 10.1046/j.1365-2486.2000.00283.x, 2000.

Wagner, S., Zotz, G., Allen, N. S., and Bader, M. Y.: Altitudinal changes in temperature responses of net photosynthesis and dark respiration in tropical bryophytes, Annals of Botany, 111, 455-465, 10.1093/aob/mcs267, 2013.

Wakeham, S. G., Lee, C., Hedges, J. I., Hernes, P. J., and Peterson, M. L.: Molecular indicators of diagenetic status in marine organic matter, Geochimica Et Cosmochimica Acta, 61, 5363-5369, 10.1016/s0016-7037(97)00312-8, 1997.

550 Wakelin, N. G., and Forster, C. F.: An investigation into microbial removal of fats, oils and greases, Bioresource Technology, 59, 37-43, 10.1016/s0960-8524(96)00134-4, 1997.

Wang, Z. Q., Ji, M. F., Deng, J. M., Milne, R. I., Ran, J. Z., Zhang, Q., Fan, Z. X., Zhang, X. W., Li, J. T., Huang, H., Cheng, D. L., and Niklas, K. J.: A theoretical framework for whole-plant carbon assimilation efficiency based on metabolic scaling theory: a test case using Picea seedlings, Tree Physiology, 35, 599-607, 10.1093/treephys/tpv030, 2015.

555 Way, D. A., and Sage, R. F.: Thermal acclimation of photosynthesis in black spruce Picea mariana (Mill.) BSP, Plant Cell and Environment, 31, 1250-1262, 10.1111/j.1365-3040.2008.01842.x, 2008.

Woodin, S. J., van der Wal, R., Sommerkorn, M., and Gornall, J. L.: Differential allocation of carbon in mosses and grasses governs ecosystem sequestration: a 13C tracer study in the high Arctic, New Phytologist, 184, 944-949, 10.1111/j.14698137.2009.03022.x, 2009.

560 Yamaguchi, J.: Respiration and the growth efficiency in relation to crop productivity, Journal of the Faculty of Agriculture, Hokkaido University, 59, 59-129, 1978.

Yan, X., Zhou, H., Zhu, Q. H., Wang, X. F., Zhang, Y. Z., Yu, X. C., and Peng, X.: Carbon sequestration efficiency in paddy soil and upland soil under long-term fertilization in southern China, Soil \& Tillage Research, 130, 42-51, 10.1016/j.still.2013.01.013, 2013.

565 Yokota, T., and Hagihara, A.: Changes in the relationship between tree size and aboveground respiration in field-grown hinoki cypress (Chamaecyparis obtusa) trees over three years, Tree Physiology, 18, 37-43, 1998.

Yoshitake, S., Uchida, M., Koizumi, H., Kanda, H., and Nakatsubo, T.: Production of biological soil crusts in the early stage of primary succession on a High Arctic glacier foreland, New Phytologist, 186, 451-460, 10.1111/j.1469-8137.2010.03180.x, 2010 .

570 Zaady, E., Kuhn, U., Wilske, B., Sandoval-Soto, L., and Kesselmeier, J.: Patterns of CO2 exchange in biological soil crusts of successional age, Soil Biology \& Biochemistry, 32, 959-966, 10.1016/s0038-0717(00)00004-3, 2000.

Zhang, S. Q., Huang, S. M., Li, J. W., Guo, D. D., Lin, S., and Lu, G. A.: Long-term manure amendments and chemical fertilizers enhanced soil organic carbon sequestration in a wheat (Triticum aestivum L.)-maize (Zea mays L.) rotation system, Journal of the Science of Food and Agriculture, 97, 2575-2581, 10.1002/jsfa.8078, 2017.

575 Zhang, W. J., Wang, X. J., Xu, M. G., Huang, S. M., Liu, H., and Peng, C.: Soil organic carbon dynamics under long-term fertilizations in arable land of northern China, Biogeosciences, 7, 409-425, 2010a. 
Zhang, W. J., Xu, M. G., Wang, X. J., Huang, Q. H., Nie, J., Li, Z. Z., Li, S. L., Hwang, S. W., and Lee, K. B.: Effects of organic amendments on soil carbon sequestration in paddy fields of subtropical China, Journal of Soils and Sediments, 12 , 457-470, 10.1007/s11368-011-0467-8, 2012.

580 Zhang, W. J., Liu, K. L., Wang, J. Z., Shao, X. F., Xu, M. G., Li, J. W., Wang, X. J., and Murphy, D. V.: Relative contribution of maize and external manure amendment to soil carbon sequestration in a long-term intensive maize cropping system, Scientific Reports, 5, 10.1038/srep10791, 2015.

Zhang, Y. J., Xu, M., Chen, H., and Adams, J.: Global pattern of NPP to GPP ratio derived from MODIS data: effects of ecosystem type, geographical location and climate, Global Ecology and Biogeography, 18, 280-290, 10.1111/j.14668238.2008.00442.x, 2009.

Zhang, Y. P., Tan, Z. H., Song, Q. H., Yu, G. R., and Sun, X. M.: Respiration controls the unexpected seasonal pattern of carbon flux in an Asian tropical rain forest, Atmospheric Environment, 44, 3886-3893, 10.1016/j.atmosenv.2010.07.027, 2010 b.

Zhao, M. S., Heinsch, F. A., Nemani, R. R., and Running, S. W.: Improvements of the MODIS terrestrial gross and net primary production global data set, Remote Sensing of Environment, 95, 164-176, 10.1016/j.rse.2004.12.011, 2005.

Zhao, M. S., and Running, S. W.: Drought-Induced Reduction in Global Terrestrial Net Primary Production from 2000 Through 2009, Science, 329, 940-943, 2010.

Zhao, Y. N., Zhang, Y. Q., Liu, X. Q., He, X. H., and Shi, X. J.: Carbon sequestration dynamic, trend and efficiency as affected by 22-year fertilization under a rice-wheat cropping system, Journal of Plant Nutrition and Soil Science, 179, 652-660, 10.1002/jpln.201500602, 2016.

Zhou, W. J., Zhang, Y. P., Schaefer, D. A., Sha, L. Q., Deng, Y., Deng, X. B., and Dai, K. J.: The Role of Stream Water Carbon Dynamics and Export in the Carbon Balance of a Tropical Seasonal Rainforest, Southwest China, Plos One, 8, 10.1371/journal.pone.0056646, 2013.

Ziska, L. H., and Bunce, J. A.: The influence of increasing growth temperature and CO2 concentration on the ratio of 600 respiration to photosynthesis in soybean seedlings, Global Change Biology, 4, 637-643, 10.1046/j.1365-2486.1998.00179.x, 1998. 
Table S1. Definition of symbols and acronyms used in the Supplementary Information. Subscripts indicating the system are not included in this table.

\begin{tabular}{|c|c|c|}
\hline Symbols and acronyms & Description & Dimensions * \\
\hline$\overline{\mathrm{AE}}$ & Assimilation efficiency & - \\
\hline$A_{\text {net }}$ & Net photosynthesis & $\mathrm{ML}^{-2} \mathrm{~T}^{-1}$ \\
\hline BPE & Biomass production efficiency & - \\
\hline$C$ & Carbon-mass & $\mathrm{M} \mathrm{L}^{-2}$ or $\mathrm{M}$ \\
\hline CSE & Carbon-storage efficiency & - \\
\hline CUE & Carbon-use efficiency & - \\
\hline $\mathrm{CUE}_{A}$ & Apparent carbon-use efficiency & - \\
\hline$E G$ & Egestion & $\mathrm{M} \mathrm{L}^{-2} \mathrm{~T}^{-1}$ or $\mathrm{M} \mathrm{T}^{-1}$ \\
\hline EX & Exudation & $\mathrm{M} \mathrm{L}^{-2} \mathrm{~T}^{-1}$ or $\mathrm{M} \mathrm{T}^{-1}$ \\
\hline$F_{\text {in }}$ & Abiotic carbon input & $\mathrm{M} \mathrm{L}^{-2} \mathrm{~T}^{-1}$ \\
\hline$F_{\text {out }}$ & Abiotic carbon output & $\mathrm{M} \mathrm{L}^{-2} \mathrm{~T}^{-1}$ \\
\hline GGE & Gross growth efficiency & - \\
\hline GPP & Gross primary productivity & $\mathrm{M} \mathrm{L}^{-2} \mathrm{~T}^{-1}$ \\
\hline$I$ & Input & $\mathrm{M} \mathrm{L}^{-2} \mathrm{~T}^{-1}$ \\
\hline NECB & Net ecosystem carbon balance $(=d C / d t)$ & $\mathrm{M} \mathrm{L}^{-2} \mathrm{~T}^{-1}$ \\
\hline NEP & Net ecosystem productivity & $\mathrm{M} \mathrm{L}^{-2} \mathrm{~T}^{-1}$ \\
\hline NGE & Net growth efficiency & - \\
\hline NPP & Net primary productivity & $\mathrm{M} \mathrm{L}^{-2} \mathrm{~T}^{-1}$ \\
\hline$O$ & Output & $\mathrm{M} \mathrm{L}^{-2} \mathrm{~T}^{-1}$ \\
\hline$R$ & Respiration & $\mathrm{M} \mathrm{L}^{-2} \mathrm{~T}^{-1}$ or $\mathrm{M} \mathrm{T}^{-1}$ \\
\hline$R_{a}$ & Autotrophic respiration & $\mathrm{M} \mathrm{L}^{-2} \mathrm{~T}^{-1}$ or $\mathrm{M} \mathrm{T}^{-1}$ \\
\hline$R_{\text {dark }}$ & Dark respiration & $\mathrm{M} \mathrm{L}^{-2} \mathrm{~T}^{-1}$ \\
\hline$R_{\text {growth }}$ & Growth respiration & $\mathrm{M} \mathrm{L}^{-2} \mathrm{~T}^{-1}$ or $\mathrm{M} \mathrm{T}^{-1}$ \\
\hline$R_{h}$ & Heterotrophic respiration & $\mathrm{M} \mathrm{L}^{-2} \mathrm{~T}^{-1}$ or $\mathrm{M} \mathrm{T}^{-1}$ \\
\hline$R_{\text {maintenance }}$ & Maintenance respiration & $\mathrm{M} \mathrm{L}^{-2} \mathrm{~T}^{-1}$ or $\mathrm{M} \mathrm{T}^{-1}$ \\
\hline$R_{\text {overflow }}$ & Overflow respiration & $\mathrm{M} \mathrm{L}^{-2} \mathrm{~T}^{-1}$ or $\mathrm{M} \mathrm{T}^{-1}$ \\
\hline$R_{\text {photo }}$ & Photorespiration & $\mathrm{M} \mathrm{L}^{-2} \mathrm{~T}^{-1}$ \\
\hline$T$ & Biomass turnover & $\mathrm{M} \mathrm{L}^{-2} \mathrm{~T}^{-1}$ or $\mathrm{M} \mathrm{T}^{-1}$ \\
\hline$U$ & Carbon uptake & $\mathrm{M} \mathrm{L}^{-2} \mathrm{~T}^{-1}$ or $\mathrm{M} \mathrm{T}^{-1}$ \\
\hline
\end{tabular}

* M: mass, L: length, T: time, -: non-dimensional quantity. 
Table S2. Data sources (online databases were last accessed on November $17^{\text {th }}, 2017$ ).

\begin{tabular}{|c|c|c|c|}
\hline System & Figures & Sources & Dataset \\
\hline Leaves & 6a & (Atkin et al., 2015) & $\begin{array}{l}\text { Existing dataset (GlobResp } \\
\text { database, } \quad \text { https://www.try- } \\
\text { db.org/TryWeb/Data.php) }\end{array}$ \\
\hline Whole plants & $5 e, 6 a$ & $\begin{array}{l}\text { (Wang et al., 2015; Atkin et al., 1996; Atkin et al., 2007; } \\
\text { Dillaway and Kruger, 2014; Frantz and Bugbee, 2005; } \\
\text { Frantz et al., 2004; Gifford, 1995; Loveys et al., 2002; } \\
\text { Nemali and van Iersel, 2004; Tjoelker et al., 1999; van } \\
\text { Iersel, 2000, 2003; Yamaguchi, 1978; Yokota and } \\
\text { Hagihara, 1998; Ziska and Bunce, 1998; Gifford, 2003; } \\
\text { Lotscher et al., 2004; Poorter et al., 1990) }\end{array}$ & Original compilation* \\
\hline $\begin{array}{l}\text { Non-vascular } \\
\text { plant } \\
\text { communities }\end{array}$ & $6 a$ & $\begin{array}{l}\text { (Green et al., 1998; Lange, 2002; Lange et al., 1998; } \\
\text { Lange et al., 2000, 2004; Lange et al., 1977; Palmqvist } \\
\text { and Sundberg, 2000; Pannewitz et al., 2005; Sundberg et } \\
\text { al., 1997; Tretiach and Geletti, 1997; Uchida et al., 2006; } \\
\text { Wagner et al., 2013; Uchida et al., 2002; Palmqvist, 2002; } \\
\text { Kappen et al., 1989; Oechel and Collins, 1976; Brostoff et } \\
\text { al., 2002, 2005; Goulden and Crill, 1997; Jeffries et al., } \\
\text { 1993; Lange et al., 1997a; Lange et al., 1993; Lange et al., } \\
\text { 2006; Lange et al., 1997b; Lange et al., 1992; Street et al., } \\
\text { 2013; Swanson and Flanagan, 2001; Woodin et al., 2009; } \\
\text { Yoshitake et al., 2010; Zaady et al., 2000; Büdel et al., } \\
\text { 2013; Lange and Green, 2002, 2004; Street, 2011) }\end{array}$ & $\begin{array}{l}\text { Original compilation based on } \\
\text { existing synthesis papers } \\
\text { (Lenhart et al., 2015; Porada et } \\
\text { al., 2013)* }\end{array}$ \\
\hline $\begin{array}{l}\text { Vascular plant } \\
\text { communities }\end{array}$ & $5 \mathrm{f}, 6 \mathrm{a}, 7$ & (Campioli et al., 2015) & $\begin{array}{l}\text { Existing dataset } \\
\text { (https://www.nature.com/article } \\
\text { s/ngeo2553\#supplementary- } \\
\text { information) }\end{array}$ \\
\hline $\begin{array}{l}\text { Microbial } \\
\text { isolates }\end{array}$ & $6 b$ & $\begin{array}{l}\text { (Gommers et al., 1988; Lehmeier et al., 2016; Min et al., } \\
\text { 2016; Roels, 1980; Collado et al., 2014; Schmidt et al., } \\
\text { 2005; Wakelin and Forster, 1997) }\end{array}$ & $\begin{array}{l}\text { Original compilation including } \\
\text { previous synthesis papers }\end{array}$ \\
\hline $\begin{array}{l}\text { Terrestrial and } \\
\text { aquatic } \\
\text { microorganisms }\end{array}$ & $\begin{array}{l}4 \mathrm{~b}, 5 \mathrm{c} \\
5 \mathrm{~d}, 6 \mathrm{~b}\end{array}$ & (Manzoni et al., 2017) & $\begin{array}{l}\text { Existing dataset } \\
\text { (http://bolin.su.se/data/Manzoni } \\
\text {-2017) }\end{array}$ \\
\hline Animals & $6 e$ & (Manzoni et al., 2017) & $\begin{array}{l}\text { Existing dataset } \\
\text { (http://bolin.su.se/data/Manzoni } \\
\text {-2017) }\end{array}$ \\
\hline $\begin{array}{l}\text { Terrestrial } \\
\text { ecosystems }\end{array}$ & $6 c, 7$ & (Luyssaert et al., 2007; Luyssaert et al., 2009) & $\begin{array}{l}\text { Existing dataset } \\
\text { (http://dx.doi.org/10.3334/ORN } \\
\text { LDAAC/949) }\end{array}$ \\
\hline
\end{tabular}




\begin{tabular}{|c|c|c|c|}
\hline $\begin{array}{l}\text { Aquatic } \\
\text { ecosystems }\end{array}$ & $6 c$ & (Hoellein et al., 2013) & $\begin{array}{l}\text { Existing dataset } \\
\text { (http://onlinelibrary.wiley.com/ } \\
\text { doi/10.4319/lo.2013.58.6.2089/a } \\
\text { bstract) }\end{array}$ \\
\hline $\begin{array}{l}\text { Terrestrial food } \\
\text { chains }\end{array}$ & $6 e, S 2$ & (McNaughton et al., 1989; Cebrian and Lartigue, 2004) & Previous synthesis papers \\
\hline $\begin{array}{l}\text { Aquatic food } \\
\text { chains }\end{array}$ & $6 e, S 2$ & $\begin{array}{l}\text { (Adams et al., 1983; Dickman et al., 2008; Downing et al., } \\
\text { 1990; Iverson, 1990; Lefebure et al., 2013; Liang et al., } \\
\text { 1981; Rock et al., 2016; Rowland et al., 2015; Cebrian and } \\
\text { Lartigue, 2004; Dunne et al., 2005) }\end{array}$ & $\begin{array}{l}\text { Original compilation including } \\
\text { previous synthesis papers* }\end{array}$ \\
\hline Soils & $6 \mathrm{~d}, 7$ & $\begin{array}{l}\text { (Hua et al., 2014; Liang et al., 2016; Purakayastha et al., } \\
\text { 2008; Tan et al., 2014; Yan et al., 2013; Zhang et al., 2015; } \\
\text { Zhang et al., 2010a; Zhang et al., 2012; Zhao et al., 2016; } \\
\text { Poeplau et al., 2017; Poffenbarger et al., 2017; Zhang et } \\
\text { al., 2017; Parton and Rasmussen, 1994; Paustian et al., } \\
\text { 1992) }\end{array}$ & Original compilation* \\
\hline Sediments & $6 \mathrm{~d}$ & $\begin{array}{l}\text { (Alin and Johnson, 2007; Ferland et al., 2014; Sobek et } \\
\text { al., 2009; Canfield, 1994; Hartnett et al., 1998; Hedges } \\
\text { and Keil, 1995) }\end{array}$ & $\begin{array}{l}\text { Original compilation including } \\
\text { previous synthesis papers }\end{array}$ \\
\hline Watersheds & $\begin{array}{l}\text { Results } \\
\text { present } \\
\text { ed in } \\
\text { the text }\end{array}$ & $\begin{array}{l}\text { (Gielen et al., 2011; Leach et al., 2016; Olefeldt et al., } \\
\text { 2012; Peichl et al., 2014; Waddington and Roulet, 2000; } \\
\text { Öquist et al., 2014; Zhou et al., 2013; Dinsmore et al., } \\
\text { 2010; Helfter et al., 2015; Zhang et al., 2010b) }\end{array}$ & Original compilation* \\
\hline
\end{tabular}

* Datasets available from the Bolin Centre Database (https://bolin.su.se/data/Manzoni-2018). 610 
Table S3. Comparisons of definitions of biological C-use efficiencies for plants and soil microorganisms.

\begin{tabular}{|c|c|c|c|}
\hline $\begin{array}{l}\text { Definitions } \\
\text { in this work }\end{array}$ & Context & $\begin{array}{l}\text { Alternative definitions in published } \\
\text { literature }\end{array}$ & Source \\
\hline $\begin{array}{l}\mathrm{CUE}_{\mathrm{A}}= \\
1-O / I\end{array}$ & $\begin{array}{l}\text { Soil microbial } \\
\text { communities }\end{array}$ & $\begin{array}{l}\text { Ecosystem-scale efficiency of microbial } \\
\text { biomass synthesis and recycling of } \\
\text { necromass/exudates }\left(\mathrm{CUE}_{E}\right)\end{array}$ & $\begin{array}{l}\text { (Eq. } 2 \text { in Geyer et al. } \\
\text { 2016) }\end{array}$ \\
\hline \multirow[t]{5}{*}{$\mathrm{GGE}=G / U$} & $\begin{array}{l}\text { Animals and } \\
\text { microorganisms }\end{array}$ & Gross growth efficiency (GGE) & (Sterner and Elser 2002) \\
\hline & $\begin{array}{l}\text { Microbial } \\
\text { communities }\end{array}$ & Carbon use efficiency (CUE) & $\begin{array}{l}\text { (Eq. } 2 \text { in Manzoni et al. } \\
\text { 2012) }\end{array}$ \\
\hline & $\begin{array}{l}\text { Soil microbial } \\
\text { communities }\end{array}$ & $\begin{array}{l}\text { Community-scale efficiency of microbial } \\
\text { biomass synthesis }\left(\mathrm{CUE}_{C}\right)\end{array}$ & $\begin{array}{l}\text { (Eq. } 1 \text { in Geyer et al. } \\
\text { 2016) }\end{array}$ \\
\hline & Individual plants & Carbon use efficiency (CUE) & (Gifford 1995) \\
\hline & Plant communities & Biomass production efficiency (BPE) & (Campioli et al. 2015) \\
\hline \multirow[t]{2}{*}{$\begin{array}{l}\mathrm{CUE}= \\
1-R / U\end{array}$} & $\begin{array}{l}\text { Soil microbial } \\
\text { communities }\end{array}$ & $\begin{array}{l}\text { Community-scale efficiency of microbial } \\
\text { biomass synthesis when } E X \approx 0 \quad \text { (also } \\
\text { denoted as } \mathrm{CUE}_{C} \text { ) }\end{array}$ & $\begin{array}{l}\text { (Figure } 3 \text { in Geyer et al. } \\
2016 \text { ) }\end{array}$ \\
\hline & Plant communities & Carbon use efficiency $(\mathrm{CUE}=\mathrm{NPP} / \mathrm{GPP})$ & $\begin{array}{l}\text { (Cannell and Thornley } \\
\text { 2000) }\end{array}$ \\
\hline
\end{tabular}


(a)

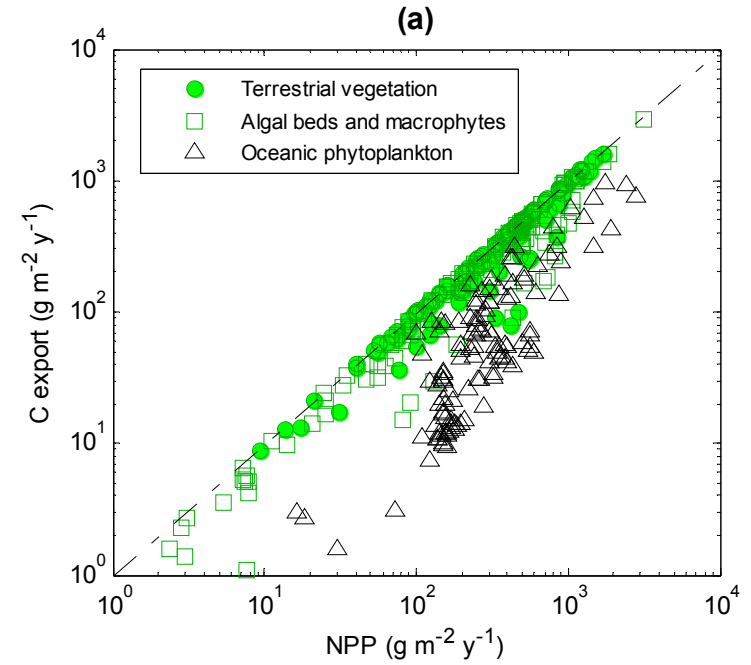

(b)

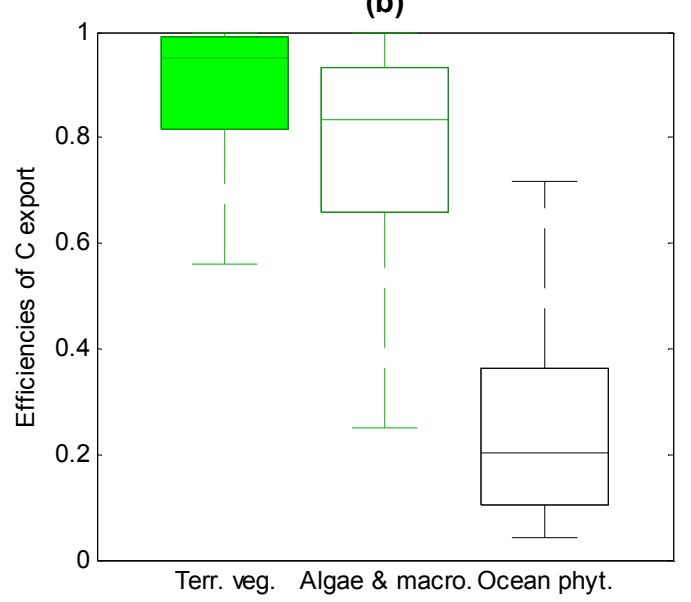

Figure S1. Comparison of the efficiencies of $\mathrm{C}$ export (exported C/primary production) among terrestrial and aquatic ecosystems. (a) Relation between $\mathrm{C}$ export rate and net primary productivity; (b) box plot of C-export efficiencies across ecosystem types. Data for terrestrial vegetation and algal beds/macrophytes is from Cebrian and Lartigue (2004); data for oceanic phytoplankton is from Dunne et al. (2005). 